\title{
Study of the compressive strength of concrete block prisms - stack and running bond
}

\section{Estudo da resistência à compressão de prismas de blocos de concreto - juntas sobrepostas e amarradas}
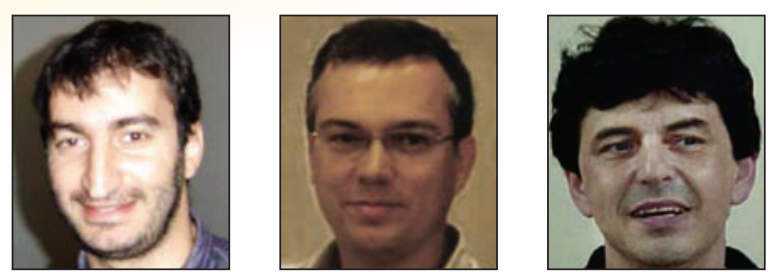

G. MOHAMAD a gihad@unipampa.edu.br

P.B. LOURENÇO ${ }^{b}$ pbl@civil.uminho.pt

H. R. ROMAN humberto@ecv.ufsc.br

\begin{abstract}
The main goal of this work is to investigate the nonlinear behavior of concrete block masonry prisms under compression, with an emphasis in the prism deformability and the failure modes. A total of 18 stack-bonded prisms have been tested, using hollow blocks of a single geometry and two different mortar types. To investigate the effect of vertical joints, the bond pattern - stack and running bond - in the prism was varied, by using half units. Finite element analysis of hollow masonry prisms was done utilizing a commercial non-linear finite element code DIANA. The numerical simulation were carried out using non-linear two dimensional 8-node elements and the biaxial stress state material was modeled by a combination of the yield conditions of Rankine and Drucker-Prager. The numerical and experimental results were compared to validate the ability to predict deformation and peak load. The results show that an analytical model cannot be formulated without understanding the interaction between block and mortar. It was observed that: the non-linearities of the masonry correspond to an increase in the lateral strain due to extensive cracking of the material and a progressive increase in the ratio between lateral and axial strains.; the cracks in the three block stacked prisms constructed with a stronger mortar were vertical on both sides; the prisms constructed with a weaker mortar had, as a consequence of localized crushing, also vertical cracks due to stress concentration at some points; the presence of a vertical joint in the prism led to the appearance of separation cracks between the middle block and the vertical mortar joint.
\end{abstract}

Keywords: concrete blocks, structural masonry, failure mode, compression behavior.

\section{Resumo}

O principal objetivo deste trabalho é investigar o comportamento não linear de prismas de blocos de concreto a compressão, com ênfase na deformabilidade e modo de ruptura. Um total de dezoito (18) prismas com blocos sobrepostos foram testados, usando blocos vazados com uma única geometria e dois traços de argamassa. Para investigar o efeito da junta vertical utilizaram-se dois meios blocos na junta intermediária dos prismas. Utilizou-se o programa comercial DIANA para simular em elementos finitos o comportamento da alvenaria estrutural. As simulações numéricas foram realizadas usando um elemento bidimensional de oito (8) nós e o estado biaxial de tensões do material foi modelado pela combinação das condições de Rankine e Drucker-Prager. Foram comparados os resultados numéricos e experimentais para validar a capacidade de prever as deformações e a carga última do conjunto. Pode se perceber pelos resultados que um modelo analítico não pode ser formulado sem um entendimento das interações entre o bloco e argamassa. Foi observado que a não linearidade da alvenaria correspondeu a um aumento nas deformações laterais devido à extensiva fissuração do material e a um progressivo aumento nas proporções entre a deformação lateral e axial; as fissuras nos prismas de três blocos construídas com argamassa forte foram verticais em ambos os lados; os prismas construídos com argamassa mais fraca tiveram um modo de ruptura por esmagamento e, também, fissuras verticais devido à concentração de tensões em alguns pontos; a presença da junta vertical nos prismas levou a uma fissura de separação entre o bloco do meio e a junta vertical de argamassa.

Palavras-chave: blocos de concreto, alvenaria estrutural, modo de ruptura, comportamento à compressão.

Universidade Federal do Pampa, Curso de Engenharia Civil, Av. Tiarajú, 810, Alegrete, RS, Brasil. gihad@unipampa.edu.br

Universidade do Minho, Departamento de Engenharia Civil, 4800-058 Guimarães, Portugal. pbl@civil.uminho.pt

Universidade Federal de Santa Catarina, Departamento de Engenharia Civil. 88040-900, Florianópolis, SC, Brasil humberto@ecv.ufsc.br 


\section{Introduction}

Unreinforced structural masonry can be considered as a system formed of distinct materials which interact to respond to vertical and horizontal loads produced by self-weight, wind and seismic activity during its useful life, with a low tensile strength, as stated by Vermeltfoort [1]. It is worth noting that the behavior of the set is dependent not only on the quality of each material employed, but also on the physic-chemical interactions between the materials. Thus, a structural masonry wall must be treated not as a function of the characteristics of its individual materials but as a composite material resulting from the interaction of the unit, of the mortar and also, when used, the grout. It is therefore important to fully understand the behavior of the 'masonry material', which can vary with the different types of unit, mortar and grout. For this reason, the structural performance of masonry walls cannot be estimated without carrying out tests on walls or prisms of the materials to be used.

\section{Mechanism failure of masonry}

The main mechanical properties of masonry walls are the compression, tensile, flexural and shear strengths. Of these properties, the most important is the compression strength because, in general, masonry walls are submitted to more intense vertical loads than horizontal loads produced by wind or seismic activity. Concrete hollow block masonry structures are currently being used extensively in many parts of the world and there is an urgent need to obtain experimental and numerical data of different bonding arrangements.

Previous studies on blockwork masonry indicate that the failure mode of masonry occurs under a biaxial state of tensile-compressive stress and the nonlinearity of the stress-strain relationship corresponds to a large increase in the lateral strain which is associated with microcracking of the concrete [2, 3, 4, 5 and 6]. To evaluate the carrying capacity of the wall and to improve the knowledge about its compressive strength, it is important to understand the mechanisms involved in deformation and failure. The distribution of stress of masonry prisms under compression are depicted in Figure 1.

Atkinson et al. [7] stated that the prediction of compressive strength and deformation characteristics of full scale masonry based on compressive tests of stack-bonded masonry prism and the inter-

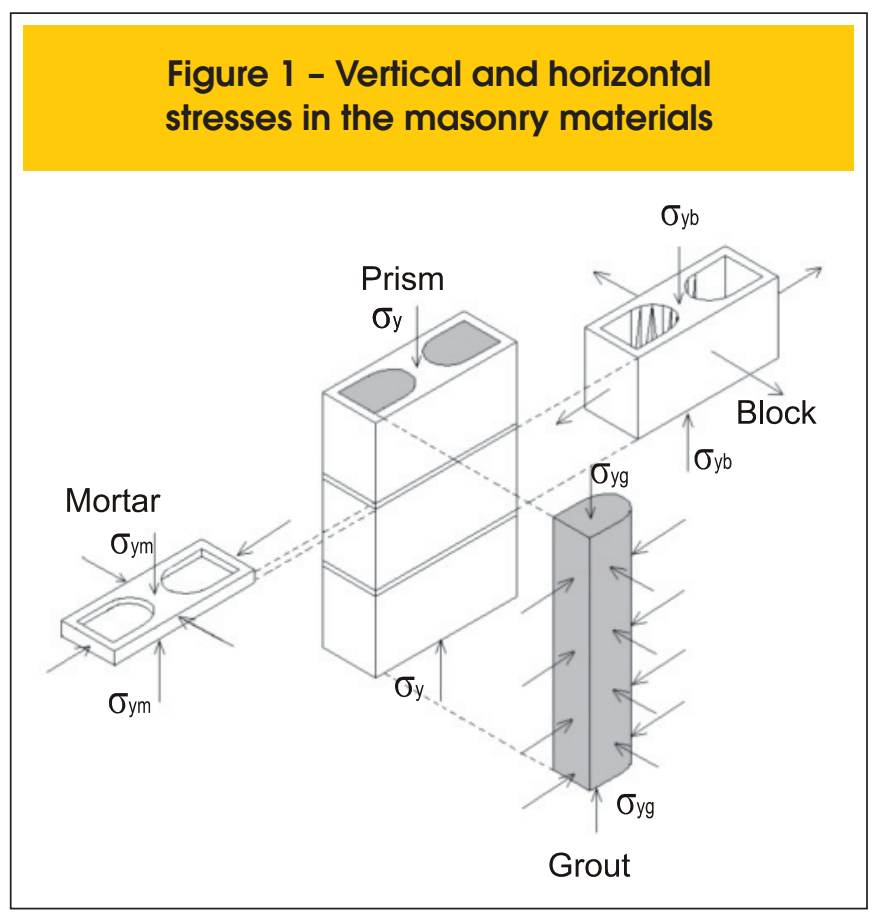

pretation of the results of prism tests have a significant influence on the allowable stress and stiffness used in masonry design. Obviously, besides the strength another relevant parameter for design is the stress-strain relationship. In particular, the elasticity modulus is of interest, which is a mechanical property influenced by different factors. It was noted that the elasticity modulus of masonry as a composite system includes the effect of the different components, namely mortar and unit.

Cheema and Klingner [8] described the failure criterion for hollow prisms using the Young's modulus ratio between mortar/block and the failure type (by mortar crushing and transverse block splitting). Material non-linearity was accounted for by using secant modulus, and the strength of the constituent materials was computed considering the effects of multiaxial stresses.

Khalaf, Hendry and Fairbain [9] did an investigation to evaluate the effect of the concrete fill strength and mortar joint type on the compressive strength and behavior of unfilled and filled blockwork masonry prisms. The experimental results were used to derive a

Figure 2 - Examples of different blocks: (a) Three-Core Conventional Block; (b) Two-Core Conventional Block; (c) Structurally Efficient Block (12)

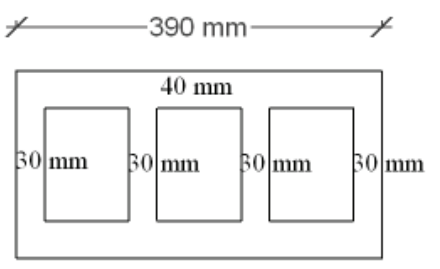

(a)

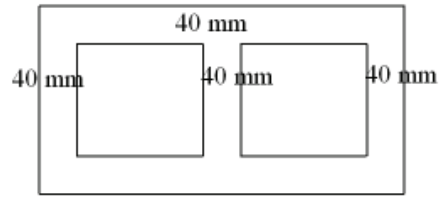

(b)

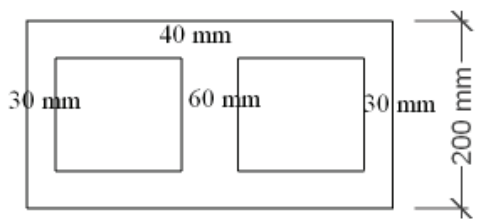

(c) 
Figure 3 - Different Bonding arrangements: (a) Stack bond prism; (b) Running bond prism (type 1); (c) Running bond prism (type 2)(12)

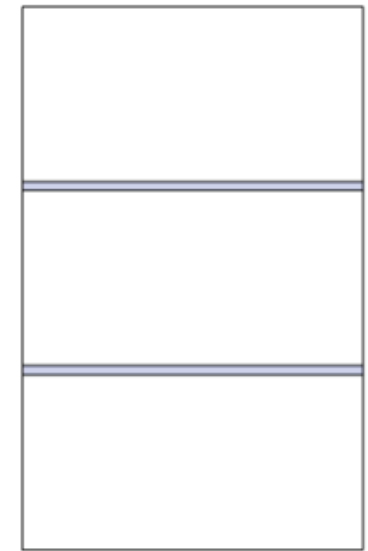

(a)

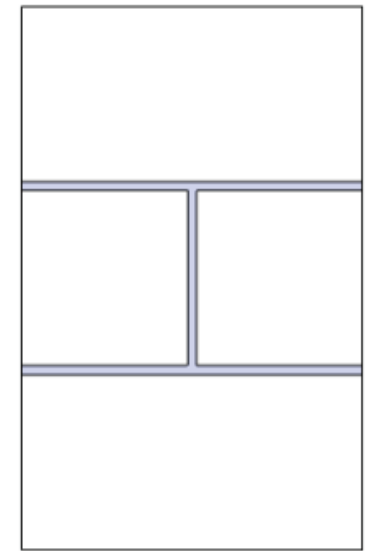

(b)

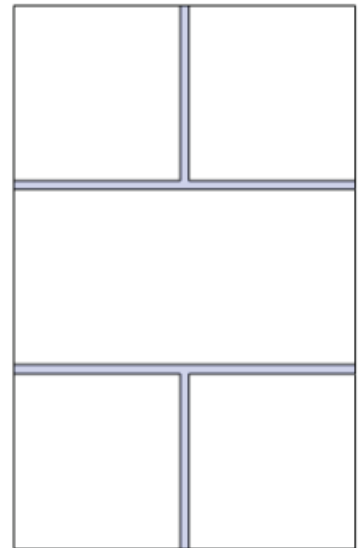

(c) simple empirical formula to determine the specified compressive strength of blockwork masonry, based on the contribution of the individual materials. The authors concluded that the mortar joint has a negligible effect on the compressive strength of the prism. Riddington and Naom [10] developed a finite element program to predict the ultimate compressive strength of masonry, using local failure criteria of the different materials. A theoretical investigation using three dimensional finite element analysis was done by Ganesan and Ramamurthy [11]. The authors discussed the effect of different parameters on the behavior of concrete hollow block masonry, such as type of hollow-block geometry, bonding arrangement, type of mortar bedding and mortar properties. To make the analysis easier, symmetry was taken into account, i.e. only one quarter of the prism of the hollow-block masonry was analyzed. To represent the range of block geometries adopted, three types of hollow block geometries and different bonding arrangements were considered. The gross and the net areas of all types of blocks were kept constant. The main conclusion of the studies was that a stackbonded prism did not represent the behavior of masonry panel in running bond and it tends to give a false value for the compressive strength. Figure 2 shows the geometry of different blocks, namely: (a) a three-core conventional block; (b) a two-core conventional block, and; (c) and a structurally efficient block. Figure 3 presents the bonding arrangement.

The failure mode of fragile materials, as concrete, occurs when the principal tensile stress reaches the limit of the tensile strength of the material. Masonry is a composite with distinct directional properties and the mortar joints are planes of weakness. To simulate the masonry complexity two strategies can be adopted - micro and macro models - depending on the level of accuracy. The models of masonry under compression have to represent the nonlinear stress-strain relation, the failure envelope under multiaxial stress condition and the post-cracking and crushing behavior of the material (Page and Shrive [12] and Lourenço [13]).

It is noted that the compressive strength and failure mode of masonry components are important for the specification of appropri- ate materials for masonry structures (Mohamad [14]) and the efficiency factor is a commonly used concept to define the adequacy of the materials. This factor is obtained by dividing the compressive strength of the masonry prism by the compressive strength of the unit and, generally, this value is lower than one and decreases with the increase in the strength of the unit.

The present paper addresses several relevant issues as a contribution for the discussion of the mechanics of hollow concrete block masonry under compression.

\section{Objectives of the study}

The main objective of this investigation is to understand the axial and lateral deformation behavior of concrete hollow block masonry prisms with different bonding arrangement, considering the influences of two different sets of block/mortar strength combinations. It is noted that most experimental results available in the international literature of masonry are focused on stack bond prism, while in this work the main goal is to understand the mechanisms involved in the deformation and failure of stack and running bond prism.

\section{Experimental methodology and program}

Initial results of the combination of two types of mortars, one block geometry and two types of prisms (stack and running bond) are presented. The mortars are in accordance to ASTM C 270 [15], corresponding to different mixes, with appropriate workability and sufficient fluidity. Two different sets of block/mortar were tested for each type of masonry prism, with mortar designated according to the standards ASTM C270 [15], EUROCODE 6 [16] and BS 5628 [17]. The industry of precast concrete produces different geometry of hollow concrete blocks (two-core or multi-core) but in this study we used only two hollow concrete blocks, because they are easily available and are the most widely used. The webs and face shells have tapered section with added flare at the top. The thickness at 


\section{Figure 4 - Two-core hollow Concrete Block in centimeters}
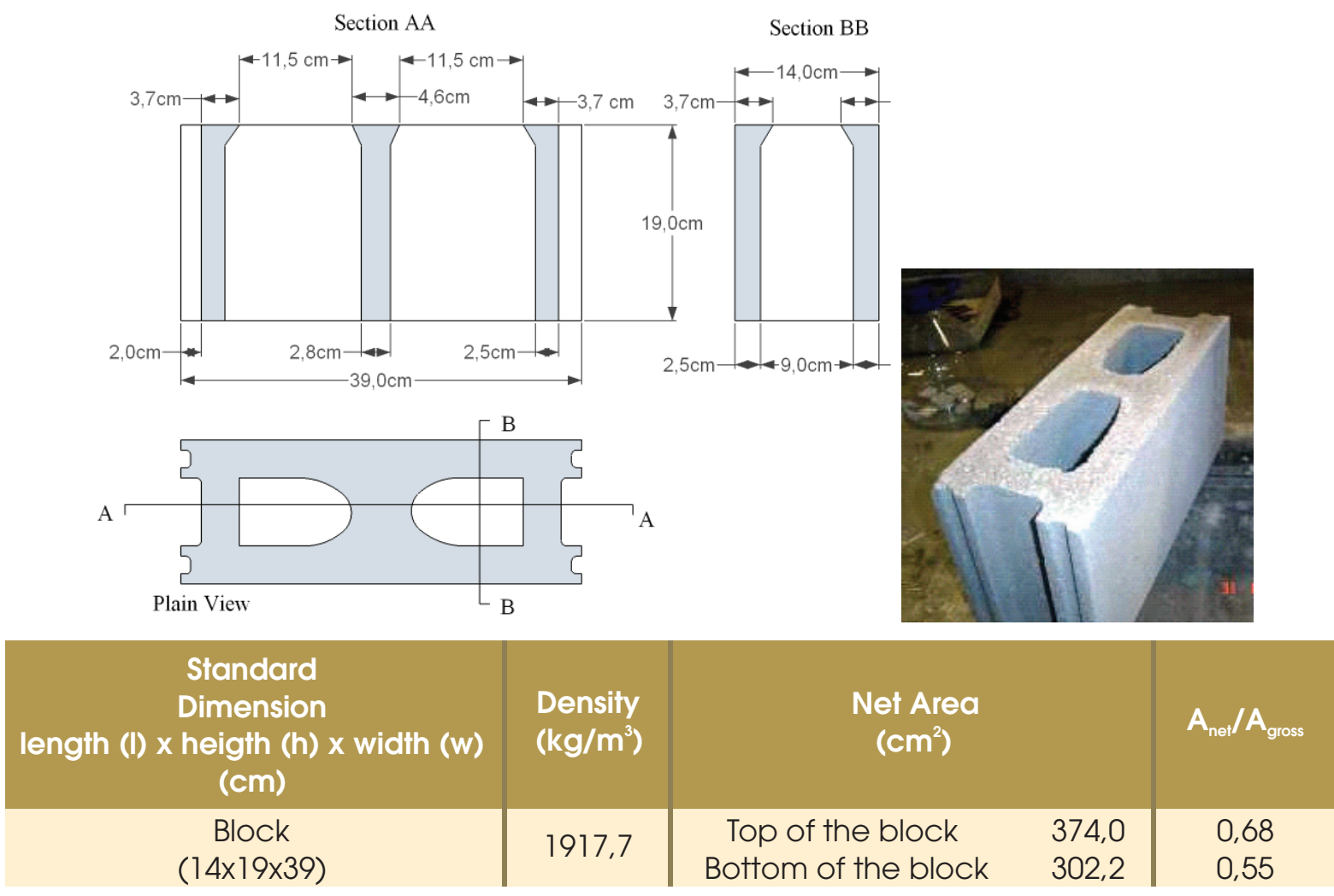

the top of the face shell and end webs was about $17 \mathrm{~mm}$ more than that at the bottom, and the central web is just over $18 \mathrm{~mm}$ thicker at the top than that at the bottom. Figure 4 shows the geometries of the two-core hollow concrete block.

The particle size distribution of the sand of mortar is important to understand the material performance in use. The results of gradation tests are presented in percentage cumulative passing and retained in different sieves size (Table 1). The value of the fineness

\begin{tabular}{|ccc|}
\hline \multicolumn{3}{|c|}{$\begin{array}{c}\text { Table 1 - Gradation tests of the } \\
\text { sands of the mortars }\end{array}$} \\
$\begin{array}{c}\text { Sieve size } \\
\text { (mm) }\end{array}$ & Cumulative $\%$ & Cumulative $\%$ \\
4,80 & 0,34 & 99,66 \\
2,40 & 6,67 & 93,32 \\
1,20 & 19,89 & 80,10 \\
0,60 & 36,28 & 63,71 \\
0,30 & 73,62 & 26,38 \\
0,15 & 90,38 & 9,61 \\
0,075 & 97,72 & 2,27 \\
Receiver & 100 & 0 \\
\hline
\end{tabular}

modulus of the sand is 2,27 , and was obtained by adding the percentage of the aggregate retained on each of the standards series of the sieves up to $0,15 \mathrm{~mm}$.

For the experimental studies two types of prism were tested, the first named ' $A$ ' containing three full concrete blocks and two bed joints. The second type of prism, named ' $\mathrm{B}$ ', is three blocks high, the middle block being composed of two half blocks with one vertical and two bed joints. The top and bottom of the block of the prisms are ground by a mechanical process to assure a flat surface, rather than use a cement paste.

The main objective of the prisms tests was to determine the influence of the vertical joint on the deformability characteristics and failure mode of the set. The total number of prisms of type A was eight, that is, four for mortar mix I and four for mortar mix II, with

\section{Table 2 - Proportion of cement, lime and sand in the mortar mixes (by volume)}

\begin{tabular}{cccc} 
Series & $\begin{array}{c}\text { Mix - Proportion of materials used (by volume) } \\
\text { Cement }\end{array}$ & Lime & Sand \\
I & 1 & 0.25 & 3 \\
II & 1 & 0.5 & 4.5 \\
\hline
\end{tabular}


Figure 5 - Positioning of the LVDTs in the tests with prisms comprising three whole blocks (type A)

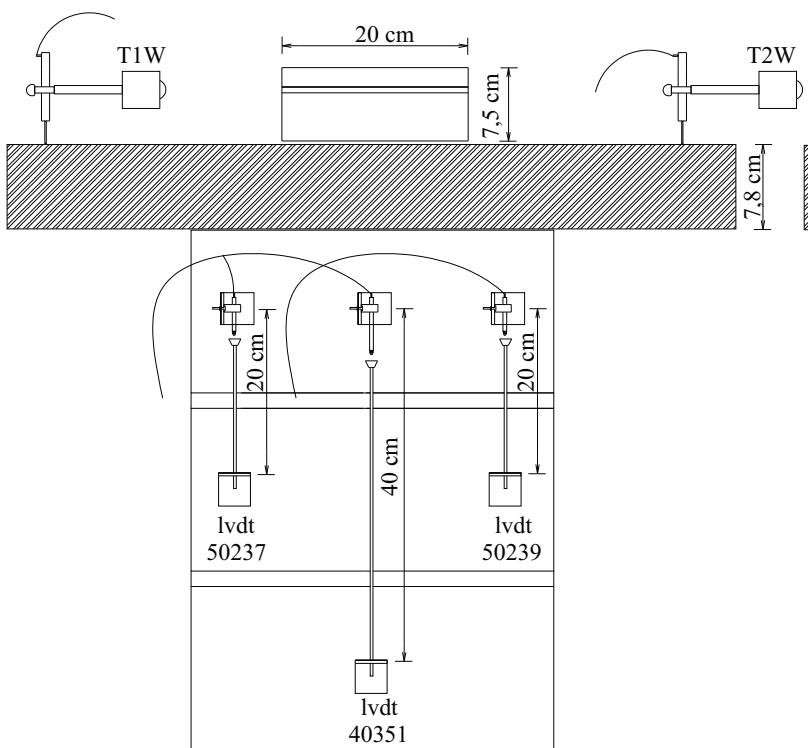

(a) FRONT

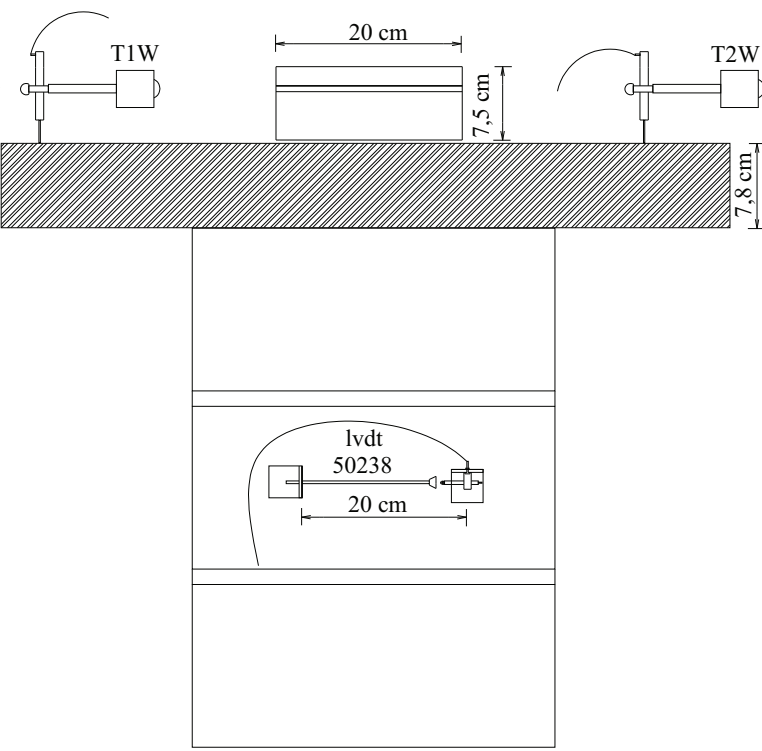

(b) BACK the mix proportion (in volume) presented in Table 2. For type B the number of prisms constructed with mixes I and II were 4 and 6 , respectively. A larger number of prisms were constructed with mix II due to the possibility that mortars with a lower strength may have a higher dispersion of the values.

The instrumentation layout of the compression test of one and two bed joints are shown in Figs. 5 and 6. A total of six LVDTs with different displacement fields were used. The LVDTs were as follows: numbers 50237, 50238 and 50239, with a maximum displacement field of $\pm 1 \mathrm{~mm}$ (measurement base of $20 \mathrm{~cm}$ ); and number 40351 with a maximum displacement field of $\pm 5 \mathrm{~mm}$ (measurement base of $40 \mathrm{~cm}$ ).

\section{Figure 6 - Positioning of the LVDTs in the tests with prisms comprising two full blocks and two half blocks (type B)}

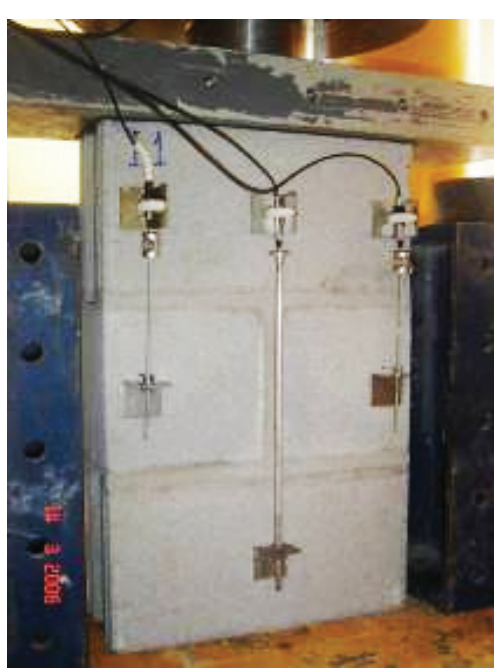

LVDTs numbers: 50237, 40351 and 50239

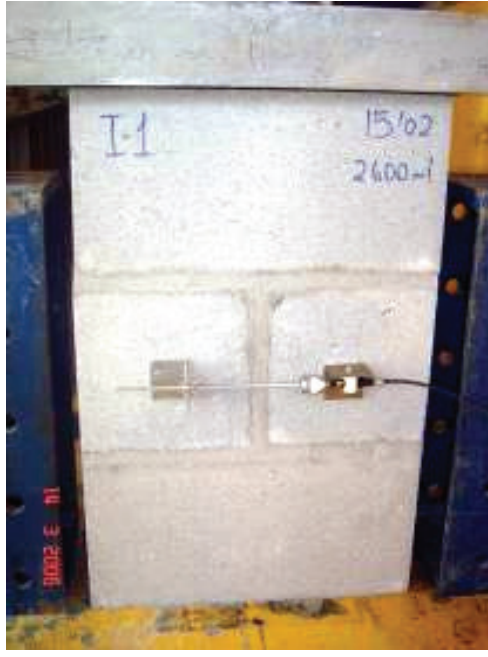

LVDT number 50238 
Table 3 - Compressive strength of prisms with statistical results

\begin{tabular}{|c|c|c|c|c|}
\hline \multirow{8}{*}{ Series } & \multicolumn{2}{|c|}{$\begin{array}{c}\text { Prisms } \\
\text { Type A (MPa) }\end{array}$} & \multicolumn{2}{|c|}{$\begin{array}{c}\text { Prisms } \\
\text { Type B (MPa) }\end{array}$} \\
\hline & I & II & I & II \\
\hline & 15,9 & 15,1 & 10,2 & 7,0 \\
\hline & 15,1 & 16,0 & 10,9 & 9,2 \\
\hline & 16,1 & 15,0 & 12,3 & 9,3 \\
\hline & 13,7 & 11,1 & 9,5 & 9,6 \\
\hline & - & - & - & 9,9 \\
\hline & - & - & - & 6,5 \\
\hline$f_{\text {paverage }}(M P a)$ & 15,2 & 14,3 & 10,7 & 8,6 \\
\hline Standard deviation (MPa) & 1,09 & 2,18 & 1,19 & 1,45 \\
\hline C.V (\%) & 7,20 & 15,2 & 11,1 & 16,9 \\
\hline
\end{tabular}

Experimental tests done by Barbosa and Hanai [18] concluded that the bending of steel plate leads to a nonuniform stress distribution. To investigate the effect of flexibility of the test machine plate on the strain distribution, two LVDT's - T1W and T2W have been attached on the top of the prisms, allowing us to characterize the load transfer and any bending deformation. For the compression tests it was concluded that a steel plate of $78 \mathrm{~mm}$ avoids concentration of stresses in the prism, providing a uniform distribution of the stress and strain. Figure 7 - Compressive strength of block,
mortar and two types of prisms

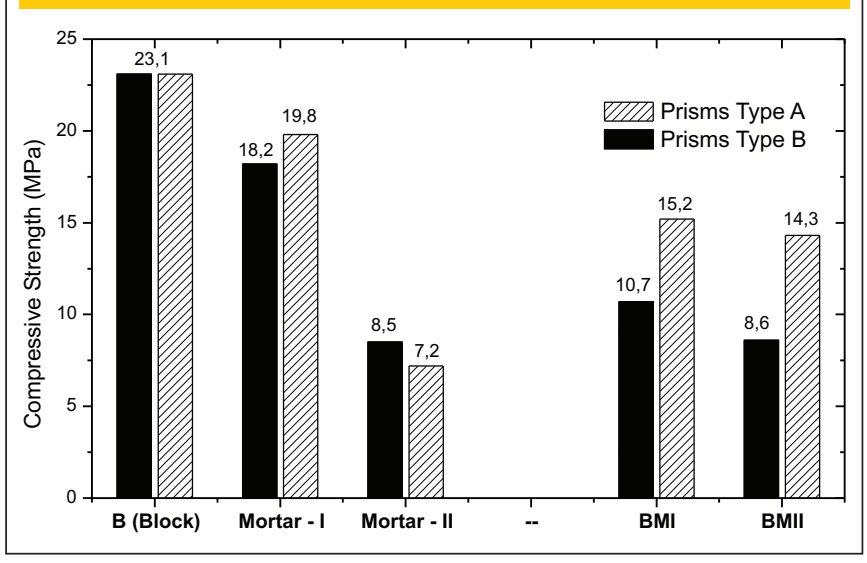

deviations and coefficient of variance (c.v.) in percentage. Figure 7 shows the bar graphics with the compressive strength of the concrete block (B), the compressive strength of the mortars (designated here as Mortar I and Mortar II) and the two types of prisms (BMI and BMII) built with the combination of block (B) with mortar M1 and M2 for stack and running bond. The values for the compressive strength of the prisms are given in net area. Table 4 presents the mean value of compressive strength of block, mortar, prisms and their relationship for each type of prisms. Fig-

\section{Experimental results of the prisms - stack and running bond}

The individual $\left(f_{\text {prism }}\right)$ and mean $\left(f_{p \text { average }}\right)$ values of compressive strength for stack-bonded and running bond prisms (type $A$ and $B$ ) are given in Table 3 , with the respective standard ure 8 summarize the average results of the relation between strength of $f_{\text {prism }} / f_{\text {block }}$ (efficiency factor) and $f_{\text {mortal }} / f_{\text {block }}$ ratios. From the experimental results it was not possible to estimate the increase in the stiffness of the mortar joint due to the confinement. Table 5 gives the mean values of the axial strain considering a single bed joint, the stress/strength ratio and the

Table 4 - Compressive strength of blocks, mortar and prisms

\begin{tabular}{|c|c|c|c|c|c|c|}
\hline Type & Series & $\begin{array}{c}f_{\text {block }} \\
(M P a)\end{array}$ & $\begin{array}{l}f_{\text {mortar }} \\
(\mathrm{MPa})\end{array}$ & $\begin{array}{l}f_{\text {paverage }} \\
\text { (MPa) }\end{array}$ & $f_{p \text { p verage/filock }}$ & $f_{p \text { mortar/fiblock }}$ \\
\hline A & I & $\begin{array}{l}23,1 \\
23,1\end{array}$ & $\begin{array}{c}19,8 \\
7,2\end{array}$ & $\begin{array}{l}15,2 \\
14,3\end{array}$ & $\begin{array}{l}0,66 \\
0,62\end{array}$ & $\begin{array}{l}0,86 \\
0,31\end{array}$ \\
\hline B & I & $\begin{array}{l}23,1 \\
23,1\end{array}$ & $\begin{array}{c}18,2 \\
8,5\end{array}$ & $\begin{array}{c}10,7 \\
8,6\end{array}$ & $\begin{array}{l}0,46 \\
0,37\end{array}$ & $\begin{array}{l}0,79 \\
0,37\end{array}$ \\
\hline
\end{tabular}




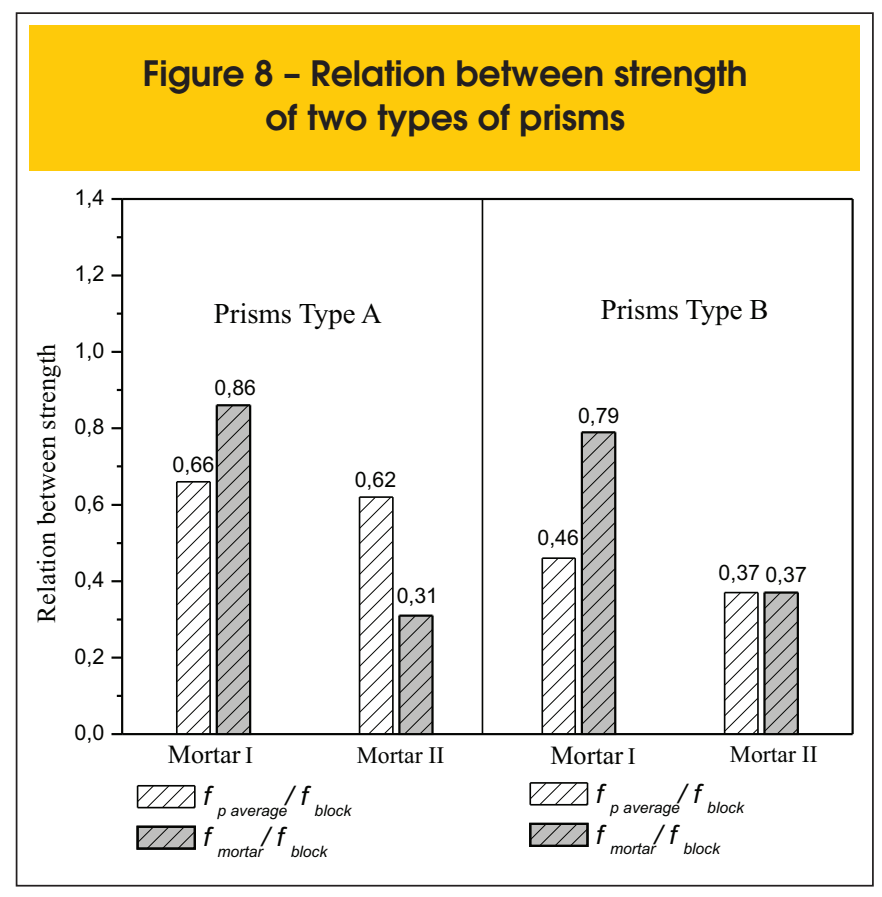

secant elasticity modulus of the prisms with a bed joint, obtained for the LVDTs designated as 50237 and 50239. It was verified that there is an increase in the average compressive strain of the prisms, due to the decrease in the compressive strength of the mortar. The secant elasticity modulus values for prisms I and II were rather close.

Table 6 shows the average results for the prism strain (type A), the stress/strength ratio, the Poisson ratio and the secant elasticity modulus of the prisms. In this case, the axial strain includes two bed joints. In the same way, the horizontal strain of the set at half the prism height was verified, allowing the calculation of the Pois- son ratio of the prism. The compressive test on the prism produces a tensile stress at mid high, as expected.

Figures 9 and 10 shows the axial and lateral stress-strain diagrams for the prisms constructed with mortar mixes I and II. For prism A with mortar mix I, an increase in the lateral strain can be observed when the stress reaches 0.80 of compressive strength. For the prisms with mortar mix II localized crushing and crumbling of the prisms was observed. There was no instantaneous increase in the lateral strain; instead, there was a continuous increase. The areas of crushing were located in the upper mortar joint of the prism for a stress level close to $50 \%$ of the compressive strength. Afterwards, crumbling of the block began, inducing the propagation of vertical cracks.

It can be observed that, for prism $B$, the vertical joint can introduce an increase in the coefficient of variation of the results. This probably occurs due to the fact that the failure process begins at the vertical joint. The average results for the compressive strength of the prisms with a vertical joint were lower than those for the prisms without a vertical joint (type A). This decrease was $42 \%$ and $66 \%$ for the mortar mixes I and II, respectively.

Table 7 gives the average results for the secant elasticity modulus for the stress/strength ratio of $30 \%$, considering one and two bed joints, with the Poisson ratio measured between the block and the vertical joint. For the prisms constructed with a vertical joint there was a progressive increase in the Poisson ratio, with values significantly higher than those of conventional three-block prisms. Also, a decrease in the value for the secant elasticity modulus of one and two bed joints for the prisms with a vertical joint was verified. The reduction in the secant elasticity modulus of the prism with a vertical joint was $18 \%$ in relation to the prism without a vertical joint. Considering two vertical joints, the average reduction was approximately $8 \%$ in relation to the cases without a vertical joint. Figures 11 and 12 show the axial and lateral stress-strain diagrams for the prisms $B$ made with mortar mixes I and II, respectively.

\begin{tabular}{|c|c|c|c|c|}
\hline \multicolumn{5}{|c|}{ Table 5 - Average experimental results for the strain of the prisms (Type A) } \\
\hline Prism & $\mathrm{n}^{*}$ & $\begin{array}{l}\text { Average axial strain (over one joint) } \\
\text { (Lvtd:50237 and 50239) }\end{array}$ & $\sigma / f_{c}$ & $\begin{array}{l}\text { Elasticity } \\
\text { Modulus (MPa) }\end{array}$ \\
\hline I & 4 & 0.0002266 & 0.31 & 20989 \\
\hline$\|$ & 4 & 0.0002447 & 0.33 & 19405 \\
\hline${ }^{*} \mathrm{n}$ is th & ers o & imens & & \\
\hline
\end{tabular}

\section{Table 6 - Average experimental results for the strain of the prisms (Type A)}

\begin{tabular}{|c|c|c|c|c|c|c|}
\hline Prism & $\mathrm{n}^{*}$ & $\begin{array}{l}\text { Axial strain } \\
\text { (over two joints) } 40351\end{array}$ & $\begin{array}{l}\text { Lateral strain } \\
50238\end{array}$ & $\sigma / f_{c}$ & $\begin{array}{l}\text { Poisson } \\
\text { ratio }\end{array}$ & $\begin{array}{c}\text { Elasticity } \\
\text { Modulus (MPa) }\end{array}$ \\
\hline I & 4 & 0.0002962 & 0.0000670 & 0.31 & 0.22 & 16056 \\
\hline$\|$ & 4 & 0.0003098 & 0.0000866 & 0.33 & 0.28 & 15326 \\
\hline
\end{tabular}


Figure 9 - Typical stress-strain diagram for prism A and mortar mix I
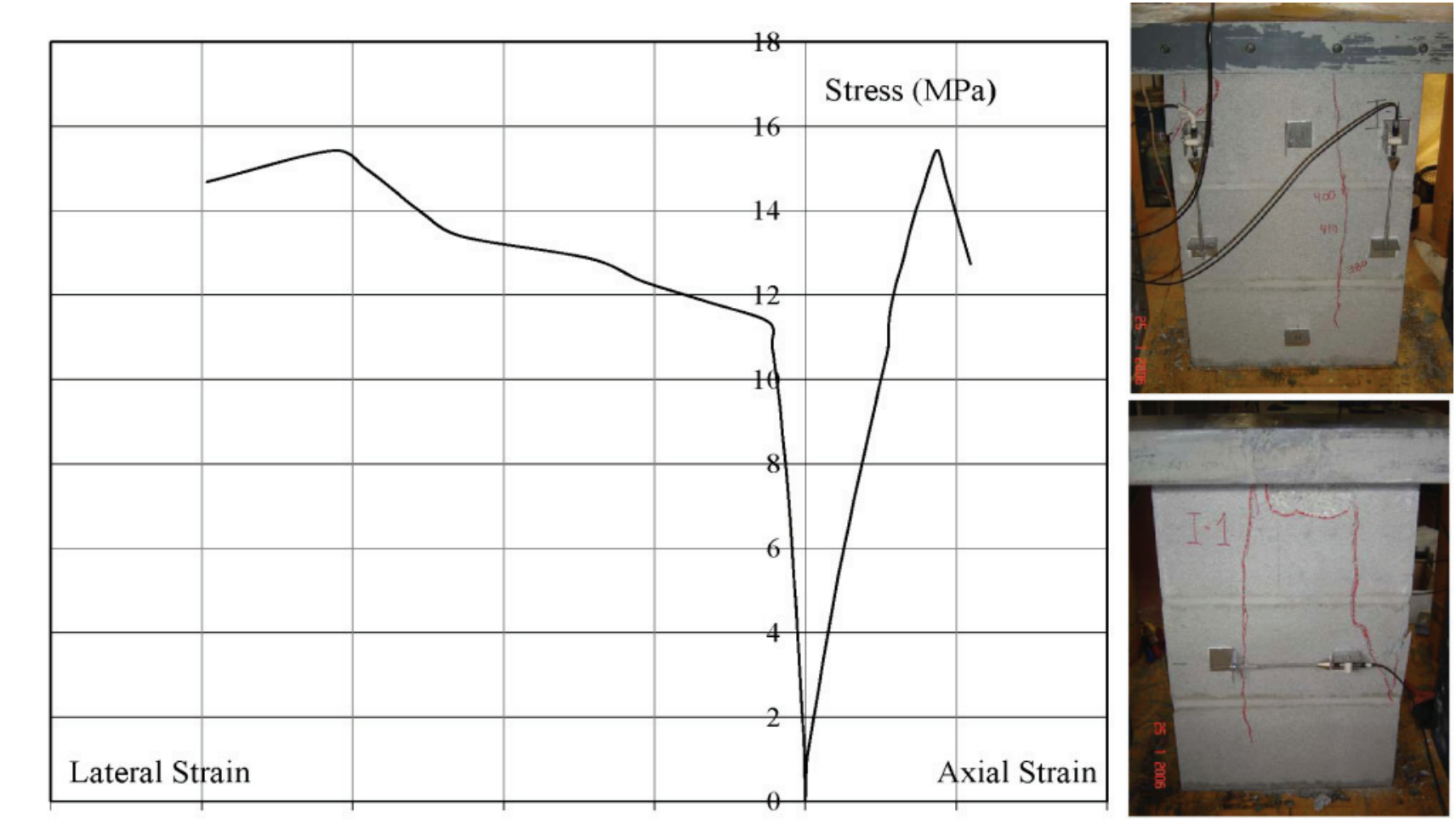

$-0,005$

$-0,004$

$-0,003$

$-0,002$

0,000

0,00

0,002

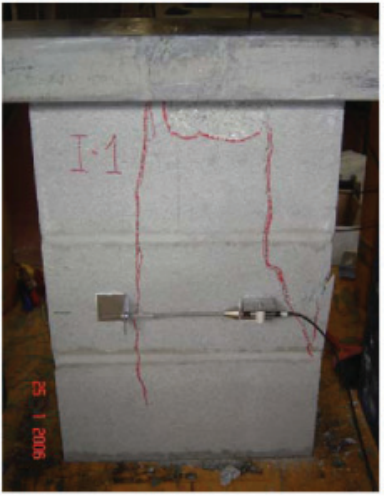

Figure 10 - Typical stress-strain diagram for prism A and mortar mix II
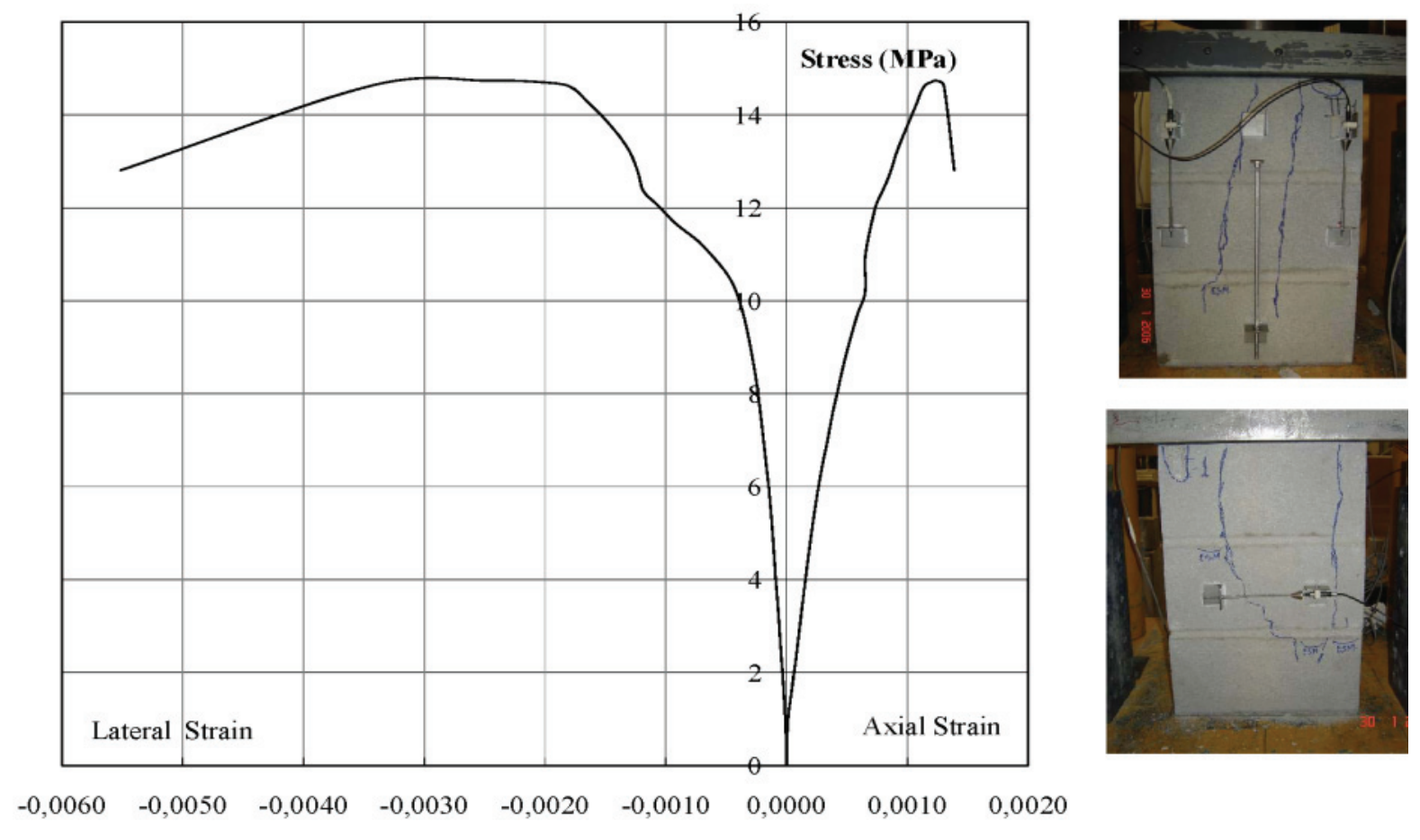
Table 7 - Elasticity modulus and Poisson ratio for the prisms with vertical joints (type B)

\begin{tabular}{cccccc} 
PRISM & $n^{*}$ & $\sigma / f_{c}$ & $\begin{array}{c}\text { Elasticity modulus } \\
\text { (over one joint) }\end{array}$ & $\begin{array}{c}\text { Elasticity modulus } \\
\text { (over two joints) }\end{array}$ & $\begin{array}{c}\text { Poisson } \\
\text { coefificient }\end{array}$ \\
I & 4 & 0.34 & 17620 & 14827 & 0.44 \\
${ }^{*} \mathrm{n}$ is the numbers of the specimens & & 16480 & 14291 & 0.50 \\
\hline
\end{tabular}

\section{Simulation of non linear behavior of prisms}

The adoption of a numerical model is generally based on the consideration that its results are deterministic and non probabilistic, which means that the mechanical properties are taken as averages, without considering the variability. The aim of this study is to obtain a model able to simulate numerically the prism compression tests, through a constitutive model using the theory of plasticity. The numerical simulations were carried out using a commercial non-linear finite element program (Diana [19]), which provided good results in analyzing this type of masonry under compression [20]. More complex models involving some kind of mesoscale seem necessary for other masonry types [21,22]. Two dimensional 8-node elements under biaxial stress state were considered using a combination of the yield conditions of Rankine and Drucker-Prager. An incrementaliterative Newton-Raphson method with arc-length control and line search was adopted to solve the equilibrium conditions and obtain convergence at the end of each load increment within prescribed tolerance limits. Figure 13 shows the quadrangular mesh of elements with eight nodes, submitted to a plane state of stress, displacement restrictions and loadings using the numerical model. The linear and non-linear mechanical characteristics of the materials used in the simulation are shown in Table 8 and Table 9, according to experimental results obtained by Mohamad et. al [23]. The mechanical properties of the mortars mixes I and II were established considering the stress state in which they were found, that is, using as a reference the triaxial compression strength envelopes, the increase in the secant elasticity modulus of the confined mortar $(E c)$ obtained in experimental tests on prisms and the decrease in the Poisson ratio due to the lateral confinement. An artificially low friction angle of $9^{\circ}$ and dilatancy of $5^{\circ}$ was adopted, in order to obtain a proper plane stress failure representation of the materials using Drucker-Prager. The fracture energy under tension and compression were obtained by experimental tests of samples cut from the block (Mohamad [14]). The experimental results for the prisms were used for comparison, named I-1, I-2, II-1 and II-2. The properties of the materials were adjusted in each simulation, according to the measured values of the masonry components.

\subsection{Numerical results}

The main objective of this simulation is to evaluate the axial and lateral deformability of block prisms, resulting from

\section{Figure 11 - Typical stress-strain diagram for prism B and mortar mix I}

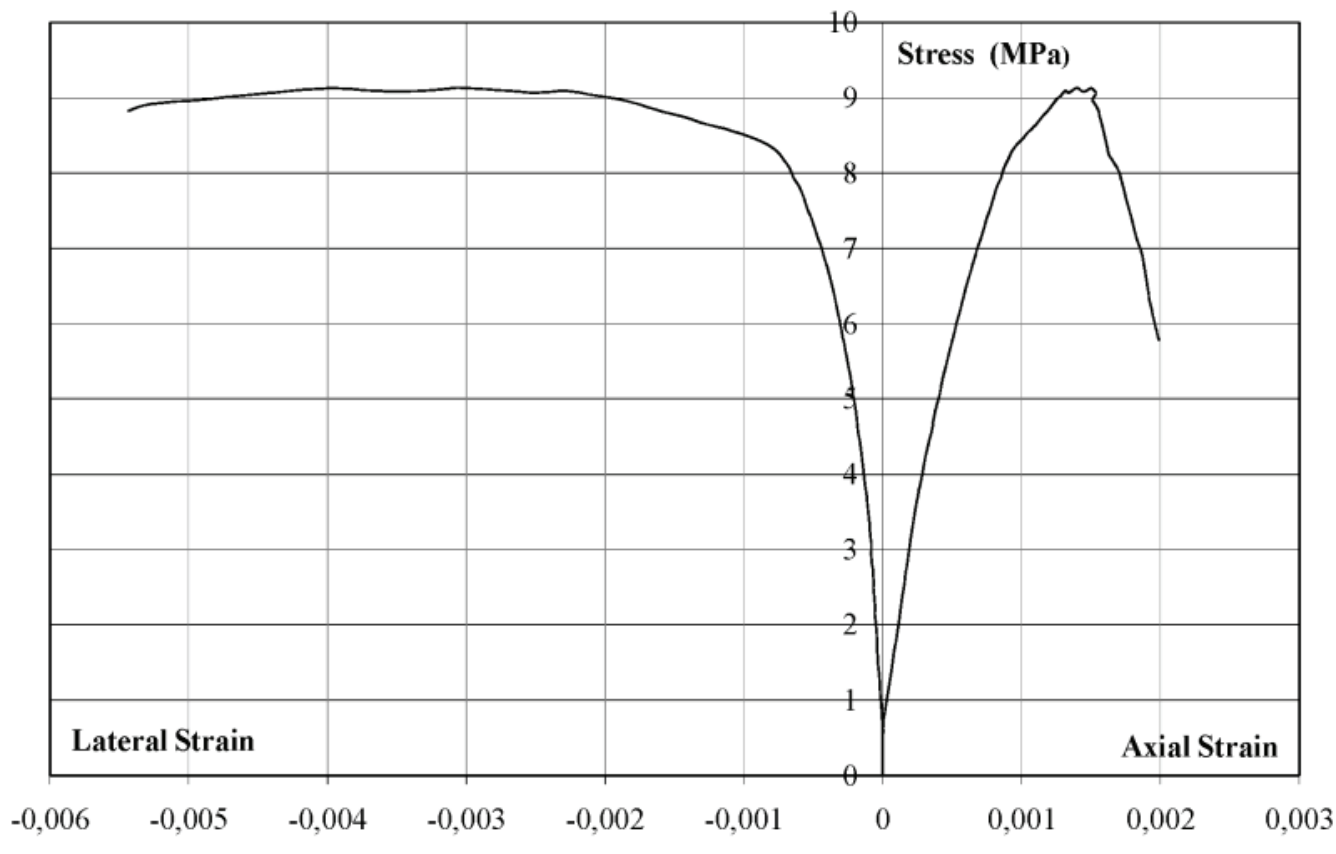




\section{Figure 12 - Typical stress-strain diagram for prism B and mortar mix II}

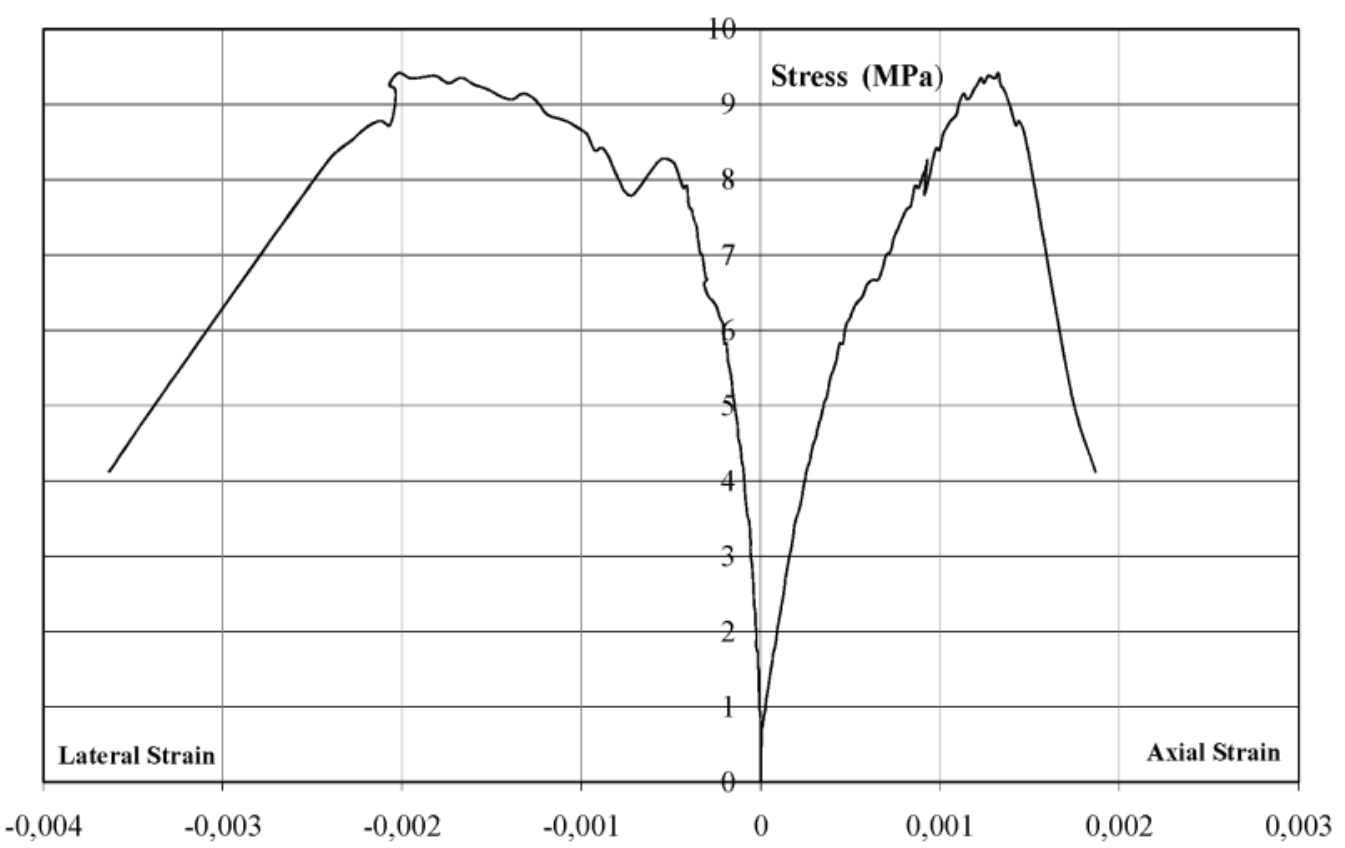

a change in the mortar mix (mixes I and II). It was verified through the stress-strain curves, for prisms I-1 and I-2, that the axial stiffness of the numerical model was lower than the experimental values, meaning that the LVDTs did not provide an adequate value for the Young's modulus. Regarding the lateral strain, the numerical model managed to represent the experimental tests up to the opening of the first crack. Figures $14,15,16$ and 17 show a comparison between the axial and lateral stress-strain curves of the prisms obtained experimen-

\section{Figure 13 - Geometrical characteristics of the block-mortar set}
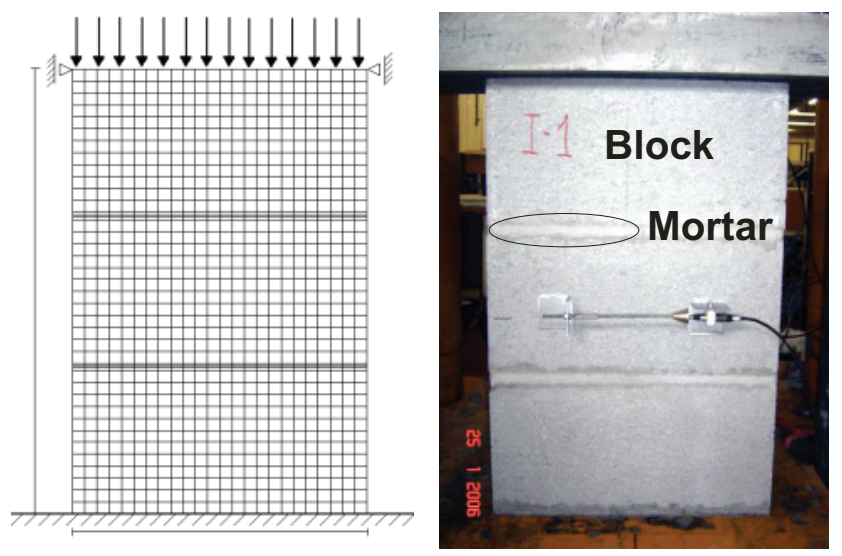

tally for mortars I and II and the results obtained numerically at similar positions.

The appearance of localized stress at a height half way up the prism for mix I induced cracks in the block, leading to an instantaneous increase in the lateral strain of the prism, as can be seen in Figs. 14 and 15. Thus, the simulation of the prism constructed with mortar mix I did not manage to capture the lateral strain increase,

\section{Figure 14 - Axial and lateral stress-strain} curves of the prism I-1

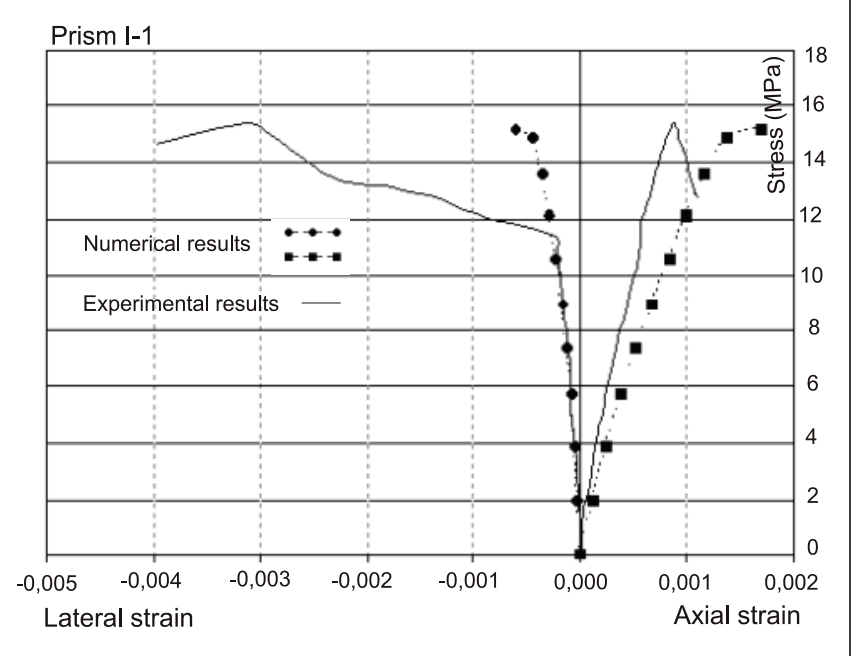




\section{Table 8 - Linear mechanical characteristics of the materials}

\begin{tabular}{|c|c|c|c|c|}
\hline Component & $E_{c}(M P a)$ & $v$ & $\mathrm{k}_{\mathrm{n}}(\mathrm{MPa} / \mathrm{mm})$ & $\mathrm{k}_{\mathrm{s}}(\mathrm{MPa} / \mathrm{mm})$ \\
\hline Block & 16000 & 0.19 & - & - \\
\hline Mortar - I & 18000 & 0.10 & - & - \\
\hline Mortar - II & 14250 & 0.10 & - & - \\
\hline Interface & - & - & 81 & 33 \\
\hline
\end{tabular}

\section{Table 9 - Non linear mechanical characteristics of the materials}

\begin{tabular}{ccccccc|} 
Component & $c(\mathrm{MPa})$ & $\mathrm{f}_{\mathrm{t}}(\mathrm{MPa})$ & $\operatorname{Sin} \varphi$ & $\operatorname{Sin} \psi$ & $\begin{array}{c}\mathbf{G f}_{\mathrm{t}} \\
(\mathbf{N} / \mathbf{m m})\end{array}$ & $\begin{array}{c}\mathbf{G f}_{\mathrm{c}} \\
(\mathbf{N} / \mathbf{m m})\end{array}$ \\
Block & 6.5 & 2.13 & 0.15 & 0.0871 & 0.094 & 12 \\
Mortar - I & 7.2 & 2.4 & 0.15 & 0.0871 & 0.094 & 13 \\
Mortar - II & 5.2 & 2.0 & 0.15 & 0.0871 & 0.080 & 11 \\
Interface & - & 2.1 & - & - & - & - \\
\hline
\end{tabular}

\section{Figure 15 - Axial and lateral stress-strain curves of the prism I-2}

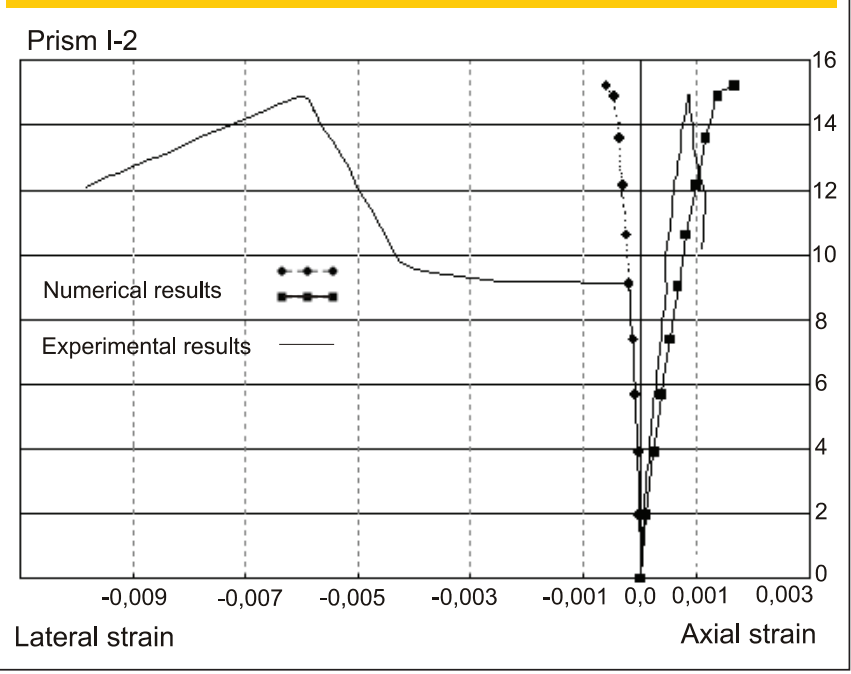

for stress levels above 0.6. $f c$ (compressive strength), but a good agreement for the failure stress was obtained.

The prisms constructed with mortar mix II provided a better agreement between the numerical and experimental results for the axial and lateral strain and the failure stress. The failure mode observed experimentally for this type of prism began with crushing of the mortar, and no sudden crack opening half way up the prism was observed, as occurred in the prism with mix I. Thus, there was better agreement between the lateral and axial stresses and strain at failure. Table 10 shows the comparative results for the ultimate axial strain obtained in the experimental tests and in the numerical simulations. The ultimate deformation is taken as the loss in the

\section{Figure 16 - Axial and lateral stress-strain curves of the prisms II- 1}

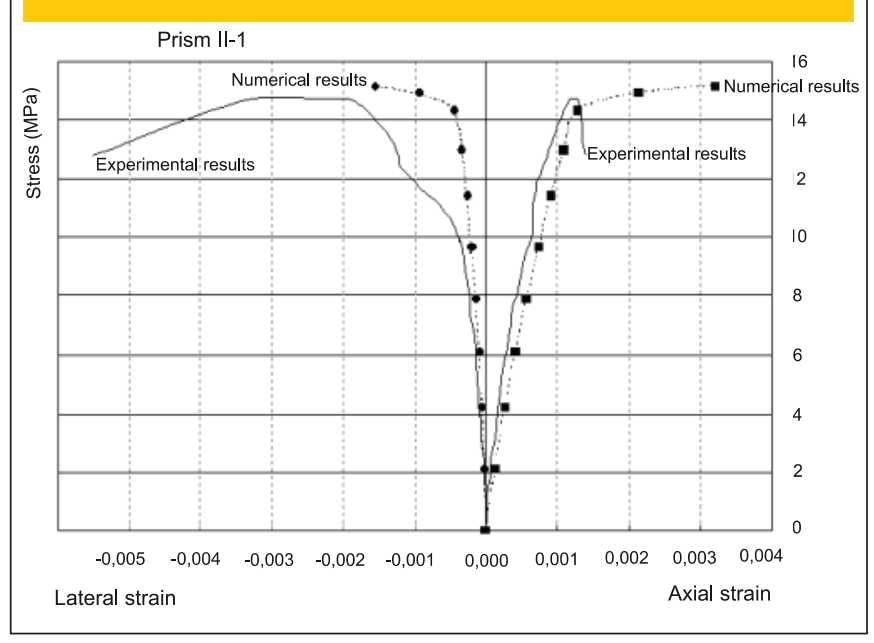

total load capacity of the component, and not the appearance of the first crack. Note that there is a significant difference in the ultimate axial strain when comparing the numerical and experimental results.

The effect of the interface between the materials (block and mortar) on the axial and lateral stress and strain values was simulated for mortar mix II. The results obtained for the prisms not considering the interface were similar to those obtained with the interface. One explanation for this would be that the interface is being constrained, that is, non linear effects will be minimized by the acting force of compression. Table 11 shows the results for the Poisson ratio, for different stress/strength ratios, obtained using the numerical model, for the mortar mixes I and II. It can be noted from these 


\section{Figure 17 - Axial and lateral stress-strain curves of the prisms II-2}

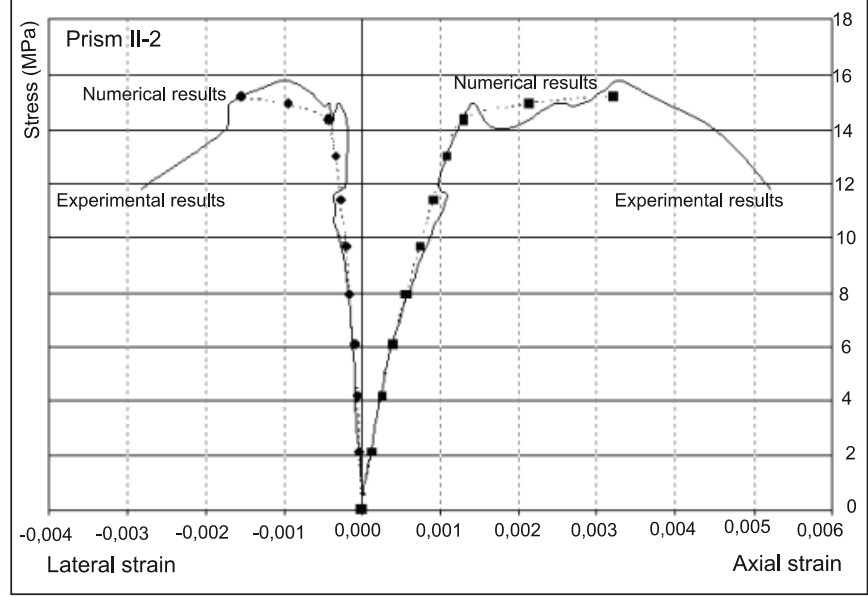

\section{Table 10 - Non linear mechanical characteristics of the materials}

\begin{tabular}{|c|c|c|}
\hline Prism & $\begin{array}{c}\mathcal{E}_{\text {xxicl ullimate strain }} \\
\text { (Experimental) }\end{array}$ & $\begin{array}{l}\varepsilon_{\text {oxial ullimate strain }} \\
\text { (Numerical) }\end{array}$ \\
\hline $1-1$ & 0.00088 & 0.00168 \\
\hline $1-2$ & 0.00086 & 0.00168 \\
\hline$\|-1$ & 0.00124 & 0.00321 \\
\hline II - 2 & 0.00332 & 0.00321 \\
\hline
\end{tabular}

\section{Table 11 - Average numerical results for the deformability of the prisms}

\begin{tabular}{|ccc|}
$\sigma / f_{c}$ & $\begin{array}{c}\text { Mortar mix I } \\
\text { Poisson ratio }\end{array}$ & $\begin{array}{c}\text { Mortar mix II } \\
\text { Poisson ratio }\end{array}$ \\
0 & 0 & 0 \\
0.13 & 0.19 & 0.19 \\
0.26 & 0.19 & 0.19 \\
0.38 & 0.21 & 0.22 \\
0.49 & 0.24 & 0.24 \\
0.59 & 0.26 & 0.27 \\
0.70 & 0.27 & 0.28 \\
0.80 & 0.29 & 0.30 \\
0.90 & 0.30 & 0.33 \\
0.98 & 0.32 & 0.43 \\
1.00 & 0.36 & 0.48 \\
\hline
\end{tabular}

results that there was an increase in the Poisson ratio from 0.19 to 0.36 for the bed joint of mix I. For mortar mix II the Poisson ratio changed from 0.19 to 0.48 .

Through the numerical analysis, a relation was obtained between the vertical and horizontal stresses for the mortar and the block. In the case of the mortar, the type horizontal stress was compressive, while the same stress was tensile for the block. For the failure of the prisms constructed with mortar mix I, the confinement stress value for the mortar was $2.19 \mathrm{MPa}$ and the tensile stresses of the block reached a maximum of $0.12 \mathrm{MPa}$. The prism of mix I showed a linear increase in the confinement stress up to a $\sigma / f c$ ratio close to 0.9 . Figures 18 and 19 show the numerical results of the stresses for a specific element in the mortar and block.

For the failure of the prisms with mix II, the confinement stress of the mortar was $5.9 \mathrm{MPa}$ and the maximum tensile stress of the block was $0.37 \mathrm{MPa}$. The prisms of mix II had a linear increase in the confinement stresses of the mortar up to a $\sigma / f c$ ratio of 0.6 . Afterwards, there was a disproportional increase in the lateral stresses, showing the strong non linear nature of the mortar set. From the numerical results it was concluded that the level of tensile stress acting in the block was not sufficient to generate tensile stress leading to a failure of the concrete due to the tension, which confirms that the representation of the collapse is essentially phe-

\section{Figure 18 - Relation between the stresses of the numerical model for the mortar and block for mix I}

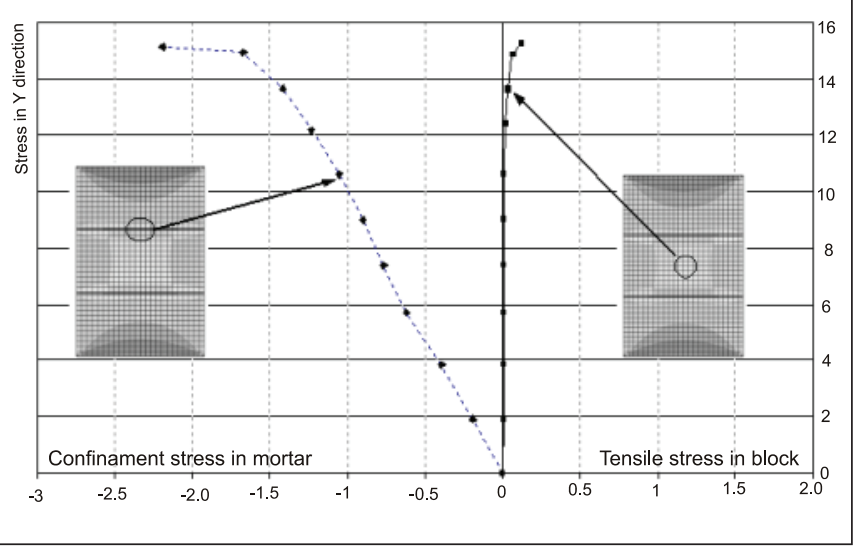

Figure 19 - Relation between the stresses of the numerical model for the mortar and block for mix II

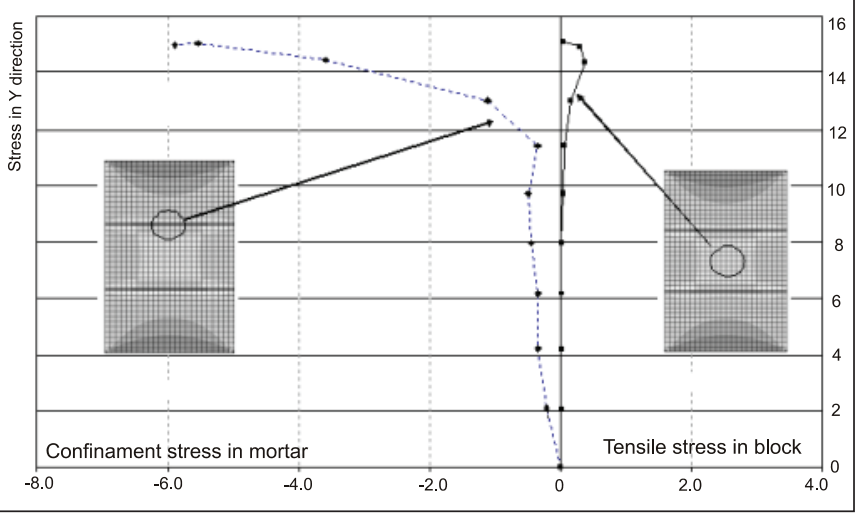


nomenological, requiring more advanced models to properly represent the failure mode, see also [22].

With the numerical results, for a selected element in the bed joint and in the block, a relation between the stresses and the axial and lateral strain was obtained. With these values the secant elasticity modulus was calculated, up to the prism failure. The relation between the ratio of elasticity modulus of the mortar to that of the block $\left(E_{\text {mortar }} / E_{\text {block }}\right)$ and the ratio of the acting stress to the compression strength $(\sigma / f c)$ was determined, as shown in Figure 20. The lower and upper limits in Fig. 20 provide a link between the behavior and the stiffness ratio of the materials. The numerical results for the prisms of mix I showed the development of tensile stresses in the mortar since the elasticity modulus was higher than that of the block and, consequently, compression stresses were generated in the block. For the prisms with mix II, the block was submitted to tensile stresses throughout the loading and the mortar was under triaxial compression, since the elasticity modulus of the mortar did not reach that of the block. This leads to the conclusion that the failure modes of the prisms were differentiated, that is, for the prism with mix I there was a progressive increase in the strain in the $x$ direction, producing stresses which lead to the material failure by tension. For the prism constructed with mix II, there was a greater strain of the bed joint, generating localized crushing and leading to failure mainly through the collapse of the joint, and the subsequent development of tensile stresses in the block.

\section{Conclusions}

The main conclusions of this work are:

- The adopted experimental test and the numerical simulation seem to be capable of giving reasonably good prediction of the ultimate compressive strength for this type of geometry block and bedding joint.

- The appearance of non-linearity in masonry corresponds to an increase in the lateral strain due to the extensive cracking of the material and to a progressive increase in the Poisson ratio.

- The cracks in the three-block prisms constructed with mortar

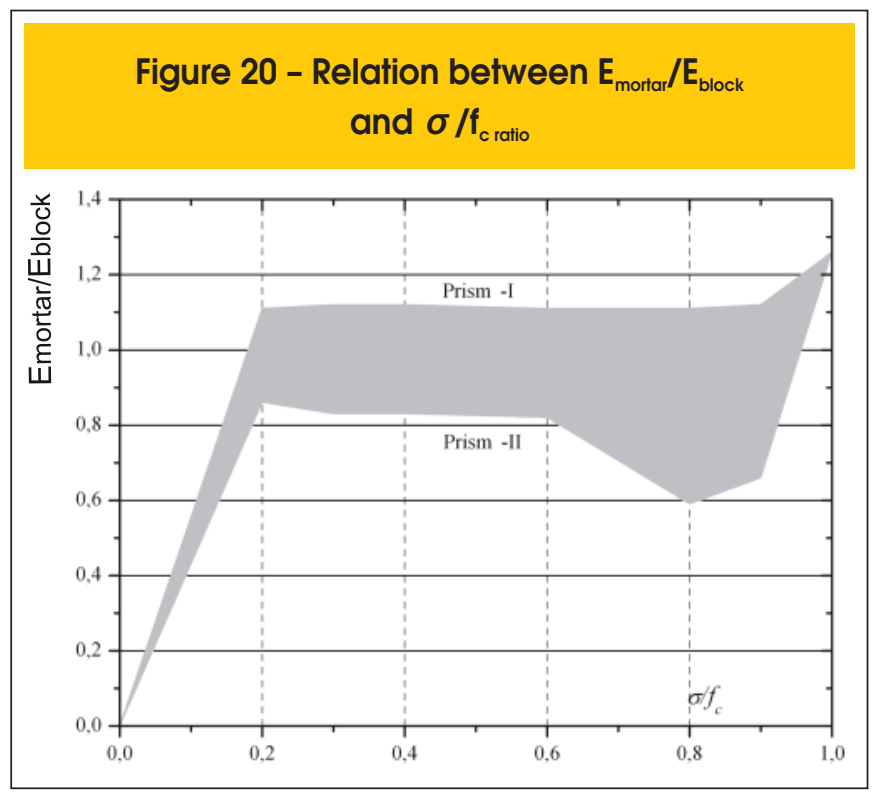

mix I were vertical, occurring in a symmetrical way on both sides. None of the samples suffered crushing in the bed joint. It could be observed visually that the prism began to behave as a single homogeneous material as the cracks were symmetrical, vertical and dispersed.

- The prisms constructed with mortar type II had, as a consequence of localized crushing, vertical cracks due to the stress concentration at some points. In the failure process, the beginning of a loss of cohesion of the mortar, the crushing of the mortar joint and the crumbling of the upper and lower surfaces of the block, were verified.

- For the prisms constructed with a vertical joint there was a progressive increase in the Poisson ratio, the values being higher than those of conventional prisms with three full blocks. The presence of a vertical joint resulted in the appearance of separation cracks between the middle block and the vertical joint of the mortar. The crack was observed when the stress reached approximately $30 \%$ of the compressive strength of the set. The prisms constructed with mortar mix type I had the following failure mode: localized crushing of the bed joint, crumbing of the block surface and vertical cracks in the block. It was verified that there was a significant reduction in the prism strength generated by the presence of a vertical joint. This reduction in efficiency is probably due to the fact that the face shell and cross webs of the block aren't juxtaposed and do not coincide with the transversal walls of the block. It may also be associated with the failure mode which the vertical joint produces. Furthermore, the presence of a vertical joint led to a considerable reduction in the elasticity modulus value.

- These studies are preliminary and further experimental tests and numerical simulations on masonry prisms must be performed considering the three-dimensional effect.

\section{References}

[01] VERMELTFOORT. A.T- Brick-mortar Interaction in masonry under pressure. $\mathrm{PhD}$ thesis. Technical University of Eindhoven. October, 2005.

[02] HAMID, A. A. AND DRYSDALE, R. G.. Behavior of concrete block masonry under axial compression. American Concrete Institute Journal, vol. 76, no. 6, pp. 707-721, 1979.

[03] HENDRY, A. W. Structural brickwork. Edited by Halsted Press book. John Wiley \& Sons. New York. USA. ISBN 0-470-27109-4, 1981.

[04] KHOO, C. L. A failure criterion for brickwork in axial compression. Thesis presented to University of Edinburgh, University of Edinburgh, Scotland, 1972.

[05] SHRIVE, N. G. Compressive strength and strength testing of masonry. Proc. 7 IBMAC, Eds. T. McNeilly and J. C. Scrivener, Melbourne, BDRI, 699-710, 1985.

[06] SHRIVE, N. G. AND EL-RAHMAN, M.. Understanding the cause of cracking in concrete: A diagnostic aid. J ournal Concrete International, vol. 7, no. 5, pp. 39-44, 1985.

[07] ATKINSON, R. H.; NOLAND, J. L., ABRAMS, D. P. AND MCNARY S. A deformation failure theory for 
stack-bond brick masonry prisms in compression. Proc. 3rd North America Masonry Conference, Boulder, Col.,TMS, Paper 18, 1985.

[08] CHEEMA, T. S. AND KLINGNER R. E. Compressive Strength of Concrete Masonry Prism. American Concrete Institute- ACI Structural Journal. January, vol. 83, no. 1, pp. 88-97, 1986.

[09] KHALAF, F. M., HENDRY, A. W. AND FAIRBAIN, D. R. Study of the compressive strength of blockwork masonry. American Concrete Institute Structural Journal, vol. 91, no. 4, pp. 367-375, 1994.

[10] RIDDINGTON, J. R. AND NAOM, N. F. Finite Element Prediction of Masonry Compressive Strength. Computers \& Structures, vol. 52, no. 1, pp. 113-119, 1994.

[11] GANESAN, T.P. AND RAMAMURTHY., K. Behavior of concrete hollow-block masonry prisms under axial compression. Journal of Structural Engineering, ASCE, vol. 118, no. 7, pp. 1751-1769, 1992.

[12] PAGE, A. W. AND SHRIVE, N.G. A critical assessment of compression tests for hollow block masonry. Masonry International, vol. 2, no. 2, pp. 35-70, 1988.

[13] LOURENÇO, P.B. Current experimental and numerical issues in masonry research. International Workshop on Masonry Walls and Earthquakes. University of Minho, Guimarães, Portugal. pp. 119-136, 2004.

[14] MOHAMAD. G. Mecanismo de ruptura de alvenarias de blocos a compressão. UMinho: Universidade do Minho. Departamento de Engenharia Civil. 312 p. Tese de Doutorado, 2007.

[15] AMERICAN STANDARD TEST METHOD. ASTM C 270. Mortar for unit masonry. Philadelphia: ASTM, 2008.

[16] EUROCODE 6. European standard - Design of masonry structures - Part 1-1: General rules for reinforced and unreinforced masonry structures. 2005

[17] BRITISH STANDARD INSTITUTE. BSI 5628: British standards institution. BSI-5628: Structural use of unreinforced masonry. London, Part. 1, 1992.

[18] BARBOSA, C. S. AND HANAI, J. B. Deformability of Hollow Concrete Blocks and Platen Effect on Axial Compression Test. 14 ${ }^{\text {th }}$ International Brick \& Block Masonry Conference. 14 IBMAC. Sydney, Australia. February, 2008.

[19] DIANA. Finite element code: user's manual - release 9. TNO Building and Construction Research, Delft.

[20] BARBOSA, C.S., LOURENÇO, P.B. AND HANAI, J.B. On the compressive strength prediction for concrete masonry prisms. Materials and Structures, vol.43, no. 3, pp. 331-344, 2010.

[21] LOURENÇO, P.B. AND PINA-HENRIQUES, J.L., Masonry micro-modelling: a continuum approach in compression. Computers \& Structures, vol. 84, no. 29-30, pp. 1977-1989, 2006.

[22] PINA-HENRIQUES, J.L. AND LOURENÇO, P.B., Masonry compression: a numerical investigation at the meso-level. Engineering Computations, vol. 23, no. 4, pp. 382-407, 2006.

[23] MOHAMAD, G; LOURENÇO, P.B. AND ROMAN, H.R. Mechanics of hollow concrete block masonry prisms under compression: Review and Prospects. Cement \& Concrete Composites. vol.29, no. 3, pp.181-192, 2007. 